\title{
The effect of energy intake of gilts on the supply of metabolizable energy and protein deposition
}

\author{
L. A. den Hartog ${ }^{1}$ and M. W. A. Verstegen ${ }^{2}$ \\ ${ }^{1}$ Department of Animal Nutrition, Agricultural University, Haagsteeg 4, 6708 PM \\ Wageningen, Netherlands \\ ${ }^{2}$ Department of Animal Husbandry, Agricultural University, Marijkeweg 40, \\ 6709 PG Wageningen, Netherlands
}

Key-words: energy intake, digestibility, metabolizable energy, fat deposition, protein deposition, gilt.

\section{Summary}

Two trials with 16 gilts of $35 \mathrm{~kg}$ and 16 gilts of $64 \mathrm{~kg}$ were carried out to determine the effects of supplying different amounts of energy combined with similar amounts of protein on metabolizable energy content of the ration. The rations were prepared by mixing two basal feeds in different ratios. Four different energy levels were used in which energy was expressed as multiples of maintenance $(\mathrm{M})$ requirement (treatments: $1=2.8-3.0 \mathrm{M} ; 2=2.4-2.6 \mathrm{M} ; 3=2.1-2.2 \mathrm{M} ; 4=1.8$ $1.9 \mathrm{M}$ ). Digestibility of energy was not influenced by treatment (mean $83.5 \%$ ). However, the different treatments consisted of diets made up with various ratios of two basal feeds. Feed components (except protein) were significantly better digested in animals at a larger weight (e.g. energy 3.2 and crude fibre 5.7 percentage units). However, the rations of weight class 2 were based on a different ratio of the basal feeds than the rations of weight class 1 . Metabolizable energy content of the ration was similar for the four diets (mean $12.4 \mathrm{~kJ} \mathrm{~g}^{-1}$ ). After correcting for differences in feed composition the metabolizability tends to be slightly depressed at the high levels of energy intake. Protein gain was determined for each gilt. The protein and fat gain were calculated from the rate of gain and daily energy intake at the same amount of digestible protein intake. Protein gain was reduced at a level of energy intake below $2.5 \mathrm{M}$. These results indicate that protein was used as energy source. Fat gain was influenced far more by feeding level than protein gain. Fat gain was diminished when energy intake was reduced.

\section{Introduction}

Factors affecting the digestibility of nutrients have been investigated in many studies (Kidder and Manners, 1978). The effect of feed intake on nutrient digestibilities is less clearly established. Some investigations have shown an inverse digestibility 
with an increasing level of feed intake (Cunningham et al., 1962, Close et al., 1983; Roth \& Kirchgessner, 1984). From other studies it appears that feed intake does not affect digestibility as long as overfeeding is avoided (Dammers, 1964; Peers et al., 1977). The composition of the feed clearly affects the digestibility of the nutrients (see review by Kidder \& Manners, 1978; Fernandez et al., 1979). The digestibility of nutrients can also be affected by the weight or age of the pigs (Nordfeldt, 1954; Fernandez et al., 1979; Wenk, 1982; Roth \& Kirchgessner, 1984). Therefore, in order to estimate the intake of digestible or metabolizable energy it is necessary to know the composition of the feed, the feeding level and the weight of the pigs.

Den Hartog (1984) performed an experiment with 680 gilts using four different levels of energy intake, while the protein intake remained the same, to study the effects of energy intake on the development of body weight in relation te reproduction.

The intake of metabolizable energy and the rate of gain at various feeding levels must be known accurately in order to calculate fat and protein gain (Cöp, 1974).

In order to calculate the metabolizable energy (ME) content of the ration supplied at the various levels of feed intake, composed from two basal diets, it was decided to determine the digestibility and the metabolizable energy content of these different rations. This experiment was performed with two weight classes of animals.

In addition, the nitrogen balance in growing pigs was determined to compare protein gain by the balance technique with protein gain by the method of Cöp (1974).

\section{Material and methods}

\section{Animals}

32 Dutch Landrace (DL) gilts from the herd of the Agricultural University were used. Animals were weaned at 5 weeks of age. Creep feed was given until 10 weeks of age. Thereafter, a high feeding level (treatment 1) was given until two weeks before transferring them into cages suited for collection of urine and faeces. During the two weeks the gilts were fed the mean level of the four treatments. The trial commenced when the gilts weighed either $35 \mathrm{~kg}$ or $64 \mathrm{~kg}$ (defined weight classes 1 and 2 , respectively). The gilts were randomly allocated to feeding level treatments. They were fed once daily according to body weight. Water was freely available.

\section{Feeding}

Four different treatments were applied. Treatments differed with respect to energy level above the maintenance requirement. Protein allowance was similar in all treatments.

\section{Protein}

Lysine is usually the first limiting amino acid for growing pigs (ARC, 1981), therefore the requirement of this amino acid is taken as reference for the supply of protein. 
Lysine supply $\left(\mathrm{g} \mathrm{d}^{-1}\right)=$ protein gain ${ }^{1} \times 0.072^{2} \times 2.2^{3}$ in which:

1 daily protein gain was assumed to be related to live weight (W) according to the equation of van Kempen \& den Hartog (1979, unpublished data). This equation was obtained from results of balance trials with 95 crossbred pigs, as follows:

$$
\text { protein gain }\left(\mathrm{g} \mathrm{d}^{-1}\right)=0.0088 \mathrm{~W}^{2}+1.8218 \mathrm{~W}+45.4831
$$

It was decided to use Equation 1 as the study was carried out with modern type pigs. This equation will give slightly higher protein gain than the averages in the literature review of Berschauer (1977). However, Berschauer also used older data obtained from pigs of a more fatty type.

${ }^{2}$ protein in the body contains $7.2 \%$ lysine (Oslage \& Schulz, 1977)

3 to ensure maximum protein gain even when protein was used as an energy source, an excess of $120 \%$ was given over and above the amount of lysine deposited in the protein gain.

\section{Energy}

For all treatments maintenance requirement of the animals housed in the cages was assumed to be $460 \mathrm{~kJ} \mathrm{ME} \mathrm{W}^{-3 / 4}$ (ARC, 1981).

Energy supply for production purposes differed between the four treatments. Energy supply was calculated from energy required for the deposition of protein and fat for all the animals in treatment 1 . Treatment 1 was thought to be adequate for protein and fat deposition at a high rate of gain. Protein deposition was calculated from live weight with equation 1 . Fat deposition was calculated from the live weight (W) on the basis of summarized literature data (Cöp, 1974). From Cöp's data it can be derived that in pigs fed ad libitum about $4 \mathrm{~g}$ fat per $\mathrm{kg}$ body weight $(\mathrm{W})$ is deposited daily (fat gain $\left(\mathrm{g} \mathrm{d}^{-1}\right)=4 \mathrm{~W}$ ). In gilts of $25 \mathrm{~kg}$, therefore, about $100 \mathrm{~g}$ of fat is deposited daily and in animals of $100 \mathrm{~kg}$ about $400 \mathrm{~g}$ of fat daily. Although castrated males may deposit more fat than gilts, the difference between sexes in the weight ranges studied here will be of minor importance (Cop, 1974). Therefore the mean as derived by Cöp was used. In order to calculate the daily requirement of metabolizable energy (ME) for protein and fat deposition it is necessary to know the energetic efficiencies. Protein retained from ME intake was calculated with an assumed partial efficiency $\left(k_{\mathrm{p}}\right)$ of $54 \%(\mathrm{ARC}, 1981)$. Energy deposited in fat was assumed to have a partial efficiency $\left(k_{f}\right)$ of $74 \%$ (Kielanowski, 1972b; Fowler et al., 1979; ARC, 1981; Close \& Verstegen, 1981). Energy required for protein and fat deposition was calculated using these partial efficiency values.

Treatments 2, 3 and 4 differed with respect to the supply of energy above maintenance and these levels were $75,56.25$ and $42.18 \%$, respectively, of that in treatment 1 . This resulted in a calculated total energy intake of about 3, 2.5, 2.1 and 1.8 times maintenance for treatments 1 to 4 , respectively.

\section{Feed composition}

In order to obtain the same protein supply on all treatments the rations used for pre- 
Table 1. Composition of the feeds.

\begin{tabular}{|c|c|c|}
\hline Ingredients & \multicolumn{2}{|c|}{ Mass fraction $(\%)$} \\
\hline Maize & 50.1 & \\
\hline Milo & 10.0 & \\
\hline Wheat & 15.0 & \\
\hline Barley & 15.0 & \\
\hline Animal fat & 1.4 & \\
\hline Cane molasses & 5.0 & 5.0 \\
\hline \multicolumn{3}{|l|}{ Soya bean meal solvent extracted } \\
\hline (with $44-47 \%$ crude protein) & & 45.3 \\
\hline Meat meal tankage $(<12.0 \%$ crude fat $)$ & & 11.0 \\
\hline Fish meal ( $8.3 \%$ crude fat $)$ & & 10.0 \\
\hline Dried potato protein & & 17.0 \\
\hline Limestone & 1.1 & 1.2 \\
\hline Calcium hydrogen phosphate & 1.6 & 10.0 \\
\hline Salt & 0.3 & \\
\hline Minerals/vitamins premix ${ }^{\prime}$ & 0.5 & 0.5 \\
\hline \multicolumn{3}{|l|}{ Calculated contents } \\
\hline Energy (MJ ME kg-1) & 13.80 & 10.50 \\
\hline Crude protein $(\%)$ & 8.95 & 47.30 \\
\hline Lysine $(\%)$ & 0.265 & 3.224 \\
\hline
\end{tabular}

${ }^{1}$ Guaranteed contents: Ca $197 \mathrm{~g} / \mathrm{kg}, \mathrm{P} 108 \mathrm{~g} / \mathrm{kg}, \mathrm{Cu} 2000 \mathrm{mg} / \mathrm{kg}, \mathrm{Mn} 4800 \mathrm{~g} / \mathrm{kg}$, Zn $8000 \mathrm{mg} / \mathrm{kg}, \mathrm{Fe}$ $16.000 \mathrm{mg} / \mathrm{kg}$. Co $50 \mathrm{mg} / \mathrm{kg}$, J $80 \mathrm{mg} / \mathrm{kg}$, Se $10 \mathrm{mg} / \mathrm{kg}$, retinol equivalent $14.000 \mu \mathrm{g} / \mathrm{kg}$, cholecalciferol equivalent $7000 \mu \mathrm{g} / \mathrm{kg}$, riboflavin $700 \mathrm{mg} / \mathrm{kg}$, nicotinamide equivalent $3600 \mathrm{mg} / \mathrm{kg}$. pantothenic acid 1400 $\mathrm{mg} / \mathrm{kg}$, choline $50.000 \mathrm{mg} / \mathrm{kg}$, vitamin B $123 \mathrm{mg} / \mathrm{kg}$, $\alpha$-tocopherol equivalent $940 \mathrm{mg} / \mathrm{kg}$, dl-methionine 40 $\mathrm{g} / \mathrm{kg}$.

paring the four treatments were made up by mixing two basal feeds in different ratios. The composition of the basal feeds are given in Table 1. The net energy contents were calculated from chemical composition and digestibility coefficients of the Dutch feeding table according to Schiemann et al. (1971). For reasons of simplicity the ME was calculated from the net energy by using the value of $70 \%$. This value is based on a summary of many experiments reported in the literature (Cöp, 1974). This approach results in a calculated $\mathrm{ME}$ content of 13.8 and 10.5 for feed $\mathrm{A}$ and $\mathrm{B}$, respectively. The daily amount of the basal feeds in the rations was calculated from the following equations:

energy requirement in $\mathrm{MJ} \mathrm{ME} \mathrm{d}^{-1}=13.8 \mathrm{~A}+10.5 \mathrm{~B}$

lysine requirement in $\mathrm{g} \mathrm{d}^{-1}=2.65 \mathrm{~A}+32.24 \mathrm{~B}$

in which $\mathrm{A}$ and $\mathrm{B}$ are $\mathrm{kg} \mathrm{d}^{-1}$ of the basal feeds. In Table 2 details about the intake of feed components for the four treatments are given.

Digestibility and balance trial

Each gilt was allowed an adaptation period for five days to its ration after being transferred into the cage. Thereafter, digestibility and metabolizability of the ra- 
Table 2. Number of balances, initial live weight $(\mathrm{kg})$ and intake of feed and feed components.

\begin{tabular}{|c|c|c|c|c|c|c|c|c|}
\hline \multirow[b]{2}{*}{ Treatment } & \multicolumn{4}{|c|}{ Weight class $1(35-45 \mathrm{~kg})$} & \multicolumn{4}{|c|}{ Weight class $2(65-75 \mathrm{~kg})$} \\
\hline & 1 & 2 & 3 & 4 & 1 & 2 & 3 & 4 \\
\hline Number of balances & 10 & 6 & 6 & 10 & 10 & 6 & 6 & 10 \\
\hline Initial live weight $(\mathrm{kg})$ & 37 & 36 & 34 & 37 & 66 & 67 & 68 & 64 \\
\hline Feed intake $\left(\mathrm{kg} \mathrm{d}^{-1}\right)$ & 1.61 & 1.37 & 1.15 & 1.07 & 2.58 & 2.25 & 1.92 & 1.61 \\
\hline Feed A/feed B ratio & 3.24 & 2.37 & 1.76 & 1.43 & 4.58 & 3.56 & 2.69 & 2.05 \\
\hline $\begin{array}{l}\text { Measured energy intake } \\
\text { (MJ ME d }{ }^{-1} \text { ) } \\
\text { Calculated energy intake }\end{array}$ & 19.5 & 16.5 & 13.8 & 13.0 & 33.0 & 29.0 & 24.5 & 20.1 \\
\hline $\begin{array}{l}\left(\mathrm{MJ} \mathrm{ME} \mathrm{d}^{-1}\right) \\
\text { Feeding level (multiples of }\end{array}$ & 20.9 & 17.5 & 14.5 & 13.3 & 34.1 & 29.4 & 24.8 & 20.5 \\
\hline maintenance requirement) & 2.8 & 2.4 & 2.1 & 1.8 & 3.0 & 2.6 & 2.2 & 1.9 \\
\hline Protein intake $\left(\mathrm{g} \mathrm{d}^{-1}\right)$ & 274 & 260 & 244 & 247 & 375 & 361 & 340 & 317 \\
\hline Crude fibre intake $\left(\mathrm{g} \mathrm{d}^{-1}\right)$ & 44 & 39 & 34 & 31 & 74 & 67 & 60 & 52 \\
\hline 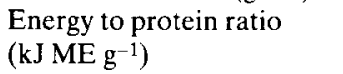 & 71.2 & 63.5 & 53.1 & 52.6 & 88.0 & 80.3 & 72.1 & 63.4 \\
\hline
\end{tabular}

Table 3. Experimental scheme for the two weight classes

\begin{tabular}{lllllllllllllllll}
\hline Animal number & 1 & 2 & 3 & 4 & 5 & 6 & 7 & 8 & 9 & 10 & 11 & 12 & 13 & 14 & 15 & 16 \\
& & & & & & & & & & & & & & & & \\
Period 1: treatment & 1 & 2 & 1 & 3 & 1 & 4 & 2 & 3 & 2 & 4 & 3 & 4 & 1 & 4 & 1 & 4 \\
Period 2: treatment & 2 & 1 & 3 & 1 & 4 & 1 & 3 & 2 & 4 & 2 & 4 & 3 & 4 & 1 & 4 & 1
\end{tabular}

tion were determined during a five-day total collection period (period 1). Each animal was then reassigned to another treatment followed by an additional adaptation period of five days. Then, a similar procedure was followed (period 2) as during period 1. Sixteen animals were used in each weight class. The experimental design is presented in Table 3. Each gilt was thus subjected to two collection periods representing two different treatments. Faeces and urine were collected separately with the use of a metal plate which divided urine from faeces directly after urine was voided and led it into a container. $100 \mathrm{ml}$ of $25 \% \mathrm{H}_{2} \mathrm{SO}_{4}$ was put in the container before collection of urine started. Faeces were preserved by adding formaline ( $4 \mathrm{ml}$ daily). Nitrogen was determined by Kjeldahl in feed, faeces and urine and was expressed as crude protein $(6.25 \times \mathrm{N})$.

The ash content of feed and faeces was determined by ashing at $550^{\circ} \mathrm{C}$. Crude fibre was determined by the method of NEN-3326 (1966). Crude fat in the faeces was determined by diethylether extraction after treatment with $\mathrm{HCl}$. Energy content in feed, faeces and urine was determined by bomb calorimetry.

\section{Analysis of data}

Data were analysed by a least squares method (Nie et al., 1975). First it was tested whether a treatment in period 1 had an effect on the treatment in period 2 (carryover effect). The effects of previous treatment and effects of period within weight class were not significant $(P>0.05)$. Data were therefore analysed again with 
treatment and weight class as factors only. No interaction was found between treatment and weight class $(P>0.05)$.

\section{Results}

Data on intake of feed and feed components for the animals in both weight classes are presented in Table 2. Crude fibre was associated with a high energy to protein ratio in the diet; unfortunately protein intake appeared to differ between the four treatments. The planned energy intake was $3 \mathrm{M}, 2.5 \mathrm{M}, 2.1 \mathrm{M}$ and $1.8 \mathrm{M}$. The realized energy intake differed somewhat from that. Energy intake expressed as multiples of maintenance requirement was higher in weight class 2 than in weight class 1. The contents of lysine analysed appeared not to be the same as the calculated contents. The lysine content in $\mathrm{g} \mathrm{kg}^{-1}$ calculated and analysed for feed $\mathrm{A}$ were 2.7 and 3.1, respectively and for feed B they were 32.2 and 29.7 , respectively. Despite this difference, however, the energy to protein ratio $\left(\mathrm{kJ} \mathrm{g}^{-1}\right)$ in the diet decreased clearly at a lower feeding level (Table 2).

\section{Digestion and metabolizability}

The effects of treatment and live weight on apparent digestibility of feed components and energy are presented in Table 4. The effects of treatment, although treatments consisted of different ratios of two basal feeds, and weight class on the digestibility of the major nutrients and on the level of metabolizable energy were

Table 4. Influence of treatment and weight class on various digestion coefficients and metabolizability of the energy.

\begin{tabular}{|c|c|c|c|c|c|c|c|c|c|}
\hline & \multicolumn{4}{|c|}{ Treatment } & \multicolumn{2}{|c|}{ Weight class } & \multirow{2}{*}{$\begin{array}{l}\text { Coefficient } \\
\text { of variation } \\
(\%)\end{array}$} & \multicolumn{2}{|c|}{ Significance } \\
\hline & 1 & 2 & 3 & 4 & 1 & 2 & & & \\
\hline Number of balances & 20 & 12 & 12 & 20 & 32 & 32 & & & \\
\hline $100(\mathrm{DE} / \mathrm{GE})$ & 83.5 & 83.8 & 83.5 & 83.4 & 81.9 & 85.1 & 2.0 & & $* *$ \\
\hline $100(\mathrm{ME} / \mathrm{DE})$ & 96.1 & 95.7 & 95.2 & 94.4 & 95.0 & 95.7 & 0.5 & $* *$ & $* *$ \\
\hline \multicolumn{10}{|l|}{ Digestion coefficients (\%) } \\
\hline Organic matter & 85.8 & 86.2 & 85.8 & 85.5 & 84.4 & 87.2 & 1.8 & & $* *$ \\
\hline Crude protein & 78.2 & 79.6 & 80.8 & 81.6 & 79.4 & 80.5 & 3.5 & $* *$ & \\
\hline Crude fibre & 38.6 & 43.2 & 47.5 & 48.1 & 41.2 & 46.9 & 20.5 & $* *$ & * \\
\hline Crude fat (after DEE-HCl) & 53.7 & 54.3 & 51.9 & 53.0 & 50.5 & 56.0 & 12.9 & & $* *$ \\
\hline NFE (after DEE-HCl) & 92.2 & 92.6 & 92.1 & 91.6 & 90.9 & 93.2 & 1.0 & $*$ & $* *$ \\
\hline $\mathrm{N}$ retention $\left(\mathrm{g} \mathrm{d}^{-1}\right)$ & 19.6 & 18.8 & 16.9 & 13.7 & 15.4 & 18.8 & 23.5 & $* *$ & $* *$ \\
\hline
\end{tabular}


Table 5. Percentage of digested protein which is retained

\begin{tabular}{lllll}
\hline & \multicolumn{4}{l}{ Treatment } \\
\cline { 2 - 5 } & 1 & 2 & 3 & 4 \\
Weight class 1 & 51.9 & 49.0 & 44.8 & 42.1 \\
Weight class 2 & 45.6 & 46.4 & 44.6 & 33.3 \\
\hline
\end{tabular}

significant in many cases $(P<0.05)$. At the treatments with higher energy intake the digestion coefficients of crude protein and crude fibre were lower than at the treatments with a low energy intake $(P<0.01)$. The digestibility of energy, organic matter and crude fat were not significantly influenced by treatment.

All coefficients of digestion were higher in animals of weight class $2(P<0.05)$ compared with animals of weight class 1 . However, the apparent digestibility of protein was not different between these classes. According to the different ratios of the basal feeds an ME content of $13.10,12.92,12.77$ and $12.58 \mathrm{~kJ} \mathrm{~g}^{-1}$ was expected from Table 1 for the four treatments, respectively. The measured ME content of the feed was similar for the four treatments: $12.46,12.47,12.37$ and $12.26 \mathrm{~kJ} \mathrm{~g}^{-1}$, respectively. By considering the difference between the expected and the measured values an increased difference at a higher energy level is found. This at least suggests a slight depression of metabolizability of the energy at a higher energy intake. As a result the increased supply of digestible and metabolizable energy, the heavier gilts (weight class $2,65-75 \mathrm{~kg}$ ) consumed per gram feed $0.65 \mathrm{~kJ}$ ME more than the gilts in weight class $1(35-45 \mathrm{~kg})$. N-retention increased significantly for treatments with high energy intake and was highest for weight class 2 (Table 4). A smaller portion of digested protein is retained at treatments with a low level of energy intake (Table 5). The determined protein (based on $\mathrm{N}$ balance) gain for animals with treatment 1 was only slightly higher than calculated according to Equation 1 (weight class 1110 and $104 \mathrm{~g}$, weight class 2135 and $130 \mathrm{~g}$, respectively).

\section{Discussion}

Development of pigs depends on environmental conditions, on feeding level and composition of the feed and on animal traits. It can be stated that the value of a ration given to a pig depends on those characteristics. Therefore it is important that the feeding value is determined with the kind of animals at the feeding level and composition which will be used in the experiment of den Hartog (1984). It had been decided that protein allowance should be similar for pigs given various energy levels. This had as a consequence that the components of the feed are not the same in the various rations. However ME content of the basal feeds were similar to that assumed (see Table 1). From the data in Table 2 it was computed that ME content of feed $\mathrm{A}$ was $13.4 \mathrm{~kJ} \mathrm{~g}^{-1}$, and for feed B it was $10.1 \mathrm{~kJ} \mathrm{~g}^{-1}$. 


\section{Digestibility}

\section{Feeding level}

Results of the digestibility trials indicate that a high energy level does not necessarily reduce the digestibility of energy. This agrees with results of studies by Dammers (1964) and by Peers et al. (1977). Digestibility of some feed components was reduced somewhat in treatments with a high energy intake (protein, crude fibre). However, it may also be the result from differences in level of crude fibre intake (Table 2) and sources of crude fibre (Table 1), since different ratios of feed $\mathrm{A}$ and feed $\mathrm{B}$ were applied. The increase of apparent digestibility of $\mathrm{N}$ at a lower energy intake may also be due to the relative smaller contribution of metabolic faecal nitrogen (MFN) (P. J. van Soest, personal communication, 1982). Since after the correction for MFN ( $2 \mathrm{~g} \mathrm{~N}$ per kg dry matter in the ration; Homb, 1972) the true digestibility of $\mathrm{N}$ did not differ significantly between treatments.

Crude fibre digestibility was lowest at the high energy level. This may be a true effect of energy intake, as observed by Cunningham et al. (1962). As stated previously the differences in digestibilities associated with the levels of energy intake have to be interpreted with respect to the rations made up from two basal feeds differing in composition.

Age

An increase in age (live weight) was found to be associated with an increased digestibility of all components $(P<0.05)$ except for protein. It should be noted that the rations of weight class 2 had another ratio of the basal feeds than those of weight class 1 (see Table 2). The differences in digestibility between the weight classes could be attributed to this. Fernandez et al. (1979), Wenk (1982) and Roth \& Kirchgessner (1984) also found that increase in weight of the pigs is associated with an increase in the digestibility of feed components.

\section{Metabolizability}

Losses of $\mathrm{CH}_{4}$ were considered to be negligible, since they are $0.7 \%$ or less when related to the intake of gross energy (van der Honing et al., 1982). Metabolizability of gross and digestible energy was clearly depressed in the treatments with a decreased energy intake. However, the difference between the highest and lowest level of energy intake was less than expected. It was found that the difference in $\mathrm{ME} / \mathrm{GE}$ ratio between treatment 1 and 4 was $1.5 \%$ (Table 2) and it was expected that this difference would be $3.6 \%$ (calculated from ME expected and GE found). This suggests that at the treatments with high energy intake the metabolizability of the energy was slightly depressed. Metabolizability of digestible energy was lower in animals of about $35 \mathrm{~kg}$ because ratio of protein to energy in the diet of these animals was higher than in animals of about $64 \mathrm{~kg}$. 


\section{Fat and protein deposition}

Variation in the ratio between fat and protein deposition in growing pigs can be achieved by varying the level of energy intake (Thorbek, 1975, Gütte et al., 1979; Metz et al., 1980).

Composition of the gain in fat and protein was calculated from rate of gain and energy intake.

Ash deposition and increase in gut-fill were assumed to be 3 and $5 \%$, respectively, of the total weight gain (Whittemore \& Fawcett, 1974).

The ratios of ash to protein and water were assumed not to be affected (Gütte et al., 1979). Protein and water deposition were closely correlated and depended on weight. Cöp (1974) analysed energy balance data derived from the literature and found that the ratio of water + protein to protein content of pigs from 2 to $150 \mathrm{~kg}$ could be formulated by:

$$
\left(1.030 \mathrm{~W}^{0.836}+0.176 \mathrm{~W}^{0.954}\right) / 0.176 \mathrm{~W}^{0.954}
$$

in which $\mathrm{W}=$ weight in $\mathrm{kg}$.

From the ratio in Equation 2, the increase in gut-fill and ash deposition, Equation 3 can be derived:

$0.92 \times$ rate of gain $=\mathrm{F}+\mathrm{P}\left(1.030 \mathrm{~W}^{0.836}+0.176 \mathrm{~W}^{0.954}\right) / 0.176 \mathrm{~W}^{0.954}$

in which: $F=$ gain in fat $\left(\mathrm{g} \mathrm{d}^{-1}\right)$

$$
\begin{aligned}
& \mathrm{P}=\text { gain in protein }\left(\mathrm{g} \mathrm{d}^{-1}\right) \\
& \mathrm{W}=\text { body weight }(\mathrm{kg})
\end{aligned}
$$

Energy required for production was calculated from the energy cost of fat and protein deposition (54 and $44 \mathrm{~kJ} \mathrm{ME}$, respectively):

energy for production $\left(\mathrm{kJ} \mathrm{ME}\right.$ intake $\left.-\mathrm{ME}_{\mathrm{m}}\right)=54 \mathrm{~F}+44 \mathrm{P}$,

in which $\mathrm{ME}_{\mathrm{m}}=460 \mathrm{~kJ} \mathrm{~W}^{-3 / 4}$

$$
\begin{aligned}
& F=\text { gain in fat }\left(\mathrm{g} \mathrm{d}^{-1}\right) \\
& \mathrm{P}=\text { gain in protein }\left(\mathrm{g} \mathrm{d}^{-1}\right)
\end{aligned}
$$

The daily rates of gain in fat and protein were calculated with Equations 3 and 4. Protein gain calculated from Equations 3 and 4 and protein gain determined from $\mathrm{N}$ balance are presented in Fig. 1. With the exception of treatment 4 the rate of protein gain determined by both methods was higher in weight class $65-75 \mathrm{~kg}$ than in weight class $35-45 \mathrm{~kg}$.

Protein gain determined by the balance technique is $5-25 \%$ higher than protein gain obtained from slaughter technique (Just Nielsen, 1970). In the present study such a difference was found when the results obtained with the $\mathrm{N}$ balance method $(\mathrm{N}$ retention $\times 6.25$ ) were compared with those obtained by calculation. Calculated protein gain was derived with results of slaughter trials by the method of Cöp (1974). However, in relative terms the two different methods were able to show 


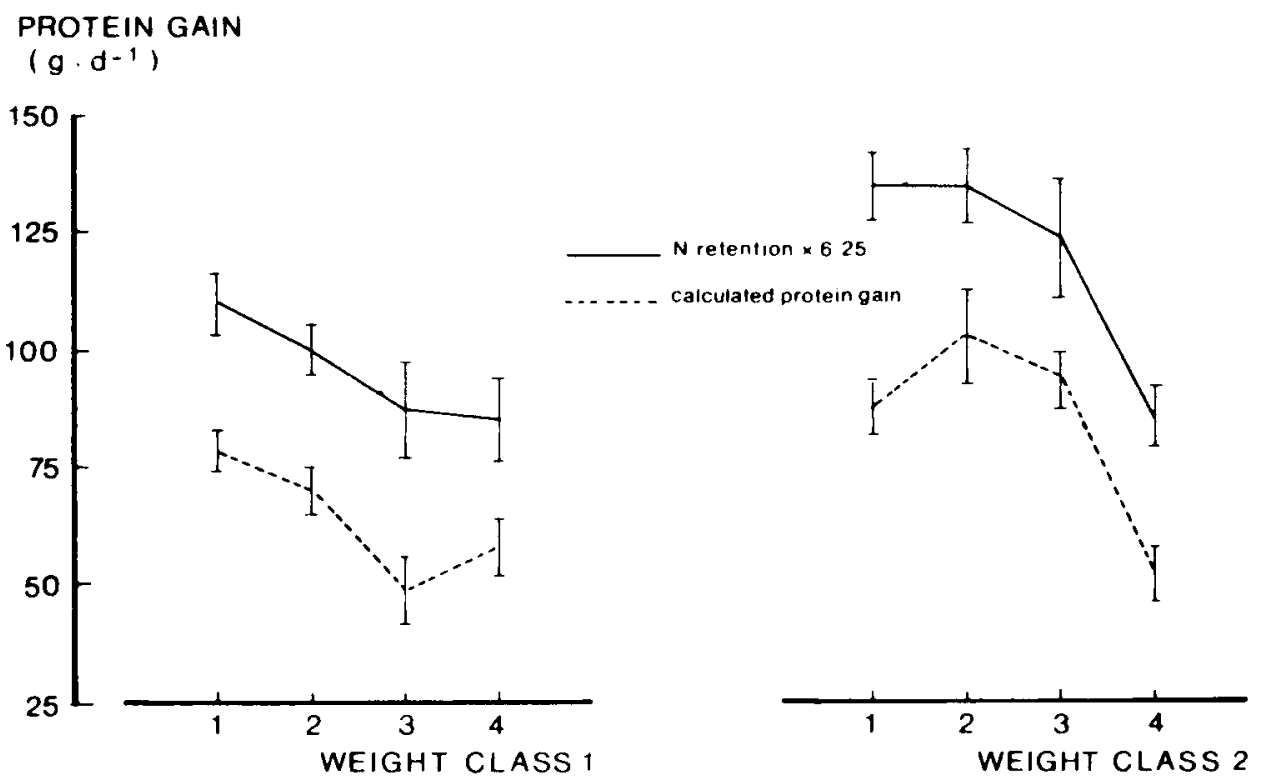

Fig. 1. Protein balance $(\mathrm{N}$ retention $\times 6.25)$ and calculated protein gain in the two weight classes.

similar differences due to treatments. The daily rate of gain and the fat gain estimated with Equations 3 and 4 are given in Fig. 2. Fat gain is closely associated with feeding level and weight class. Interaction of weight class with feeding level was significant $(P<0.001)$. Fat gain at the highest energy level in period 1 was $48 \%$ of that in period 2, while the percentage for the lowest level was 44 . Table 6 presents the coefficients of correlation between protein gain and rate of gain. The correlation coefficients between protein gain as determined by both methods ranged from 0.42 to 0.63 and were lower than correlation coefficients between $\mathrm{N}$ balance and rate of gain. Calculated protein gain was related more to the rate of body weight gain than to the measured protein gain. This can be expected because these characteristics are partly autocorrelated.

The aim of the experiment of den Hartog (1984) was to study the effect of a reduction in energy intake on the development of gilts. It was tested whether an equal $\mathrm{N}$ intake resulted in equal protein gain. Results showed that at the low energy level, protein gain is reduced (Fig. 1). This means that protein gain is reduced at limited levels of energy intake despite of the abundancy of protein in the feed.

Pigs fed a low energy level are not able to express their full genetic capacity for protein deposition (Kielanowski, 1972a; Metz et al., 1980). Apparently, energy intake levels at 1.8 and 2.1 times maintenance $(1.8 \mathrm{M}$ and $2.1 \mathrm{M})$ are too low for high protein gain. The present experiment also showed that at the low level of $1.8 \mathrm{M}$, the estimated fat deposition was 56 and $129 \mathrm{~g} \mathrm{~d}^{-1}$ in the two weight classes, respectively. Apparently, protein will only be deposited at a maximum rate if fat can be depos- 


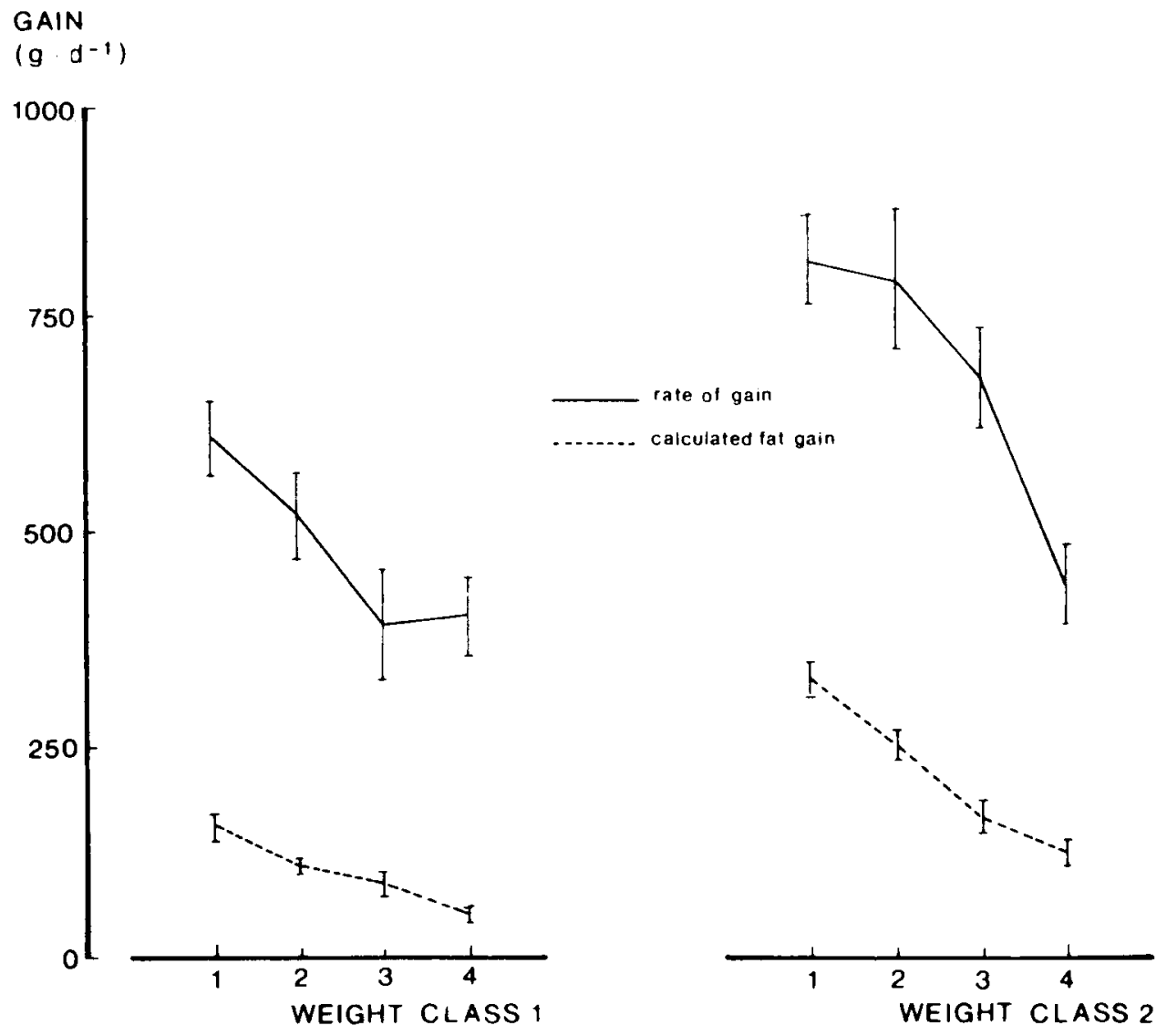

Fig. 2. Rate of gain and calculated fat gain in the two weight classes.

Table 6. Coefficients of correlation between protein gain and rate of gain.

\begin{tabular}{lllllll}
\hline & $\begin{array}{l}\text { Between- } \\
\text { treatment } \\
\text { means }\end{array}$ & \multicolumn{2}{l}{ Within treatment } & & \\
\cline { 5 - 7 } & & & 2 & 3 & 4 \\
Calculated protein gain and N balance & $0.97^{* *}$ & $0.42^{*}$ & $0.63^{* *}$ & $0.55^{*}$ & $0.61^{* *}$ \\
Calculated protein gain and rate of gain & $0.94^{* *}$ & $0.87^{* *}$ & $0.94^{* *}$ & $0.97^{* *}$ & $0.97^{* *}$ \\
$\mathrm{~N}$ balance and rate of gain & $0.99^{* *}$ & $0.66^{* *}$ & $0.80^{* *}$ & $0.65^{* *}$ & $0.67^{* *}$ \\
\hline
\end{tabular}

* $P<0.05$

** $P<0.01$

ited at a level as high as the maximum protein gain (Figs. 1 and 2).

Wenk et al. (1976) found that at a high feeding level the extra fat is mostly deposited intra-muscular. In addition, Metz et al. (1980) found that energy restriction in pigs affected muscular protein deposition less than total body protein deposition. 
Any effect of nutrient restriction of pigs may have a different consequence for development of different tissues and organs depending on the level of nutrients required for each tissue and organ and their respective priority. It can therefore be expected that any specific effects of nutrient supply on reproduction will be associated with this phenomenon.

\section{References}

A. R. C., 1981. The nutrient requirements of pigs. Commonwealth Agricultural Bureaux, Slough, U.K., 307 pp.

Close, W. H., F. Berschauer \& R. P. Heavens, 1983. The influence of protein: energy value of the ration and level of feed intake on the energy and nitrogen metabolism of the growing pig. British Journal of Nutrition 49: 255-269.

Close, W. H. \& M. W. A. Verstegen, 1981. Factors influencing thermal losses in non-ruminants: a review. Livestock Production Science 8: 449-463.

Cöp, W. A. G., 1974. Protein and fat deposition in pigs in relation to bodyweight gain and feeding level. Thesis, Agricultural University, Wageningen, $74 \mathrm{pp}$.

Cunningham, H. M., D. W. Friend \& J. G. W. Nicholson, 1962. The effect of age, body weight, feed intake and adaptability of pigs on the digestibility and nutritive value of cellulose. Canadian Journal of Animal Science 42: 167-175.

Dammers, J., 1964. Verteringsstudies bij het varken. Factoren van invloed op de vertering der voedercomponenten en de verteerbaarheid der aminozuren. Thesis, University of Leuven, $152 \mathrm{pp}$.

Fernandez, J. A., A. Just \& H. Jørgensen, 1979. Comparison of the ability of growing pigs and sows to digest different feedstuffs. 30th annual meeting of E.A.A.P., p. 5.7.

Fowler, V. R., M. F. Fuller, W. H. Close \& C. T. Whittemore, 1979. Energy requirements for the growing pig. In: L. E. Mount (Ed.), Energy metabolism, pp. 151-156.

Gütte, J. O., E. Heunisch \& T. Heine, 1979. Untersuchungen zum einfluss unterschiedlicher Energieversorgung auf Wachstum, Futterverwertung und Zusammensetzung des Körpers von Schweinen 3. Der mittlere tägliche Stoffansatz im Tierkörper von 25 bis $99 \mathrm{~kg}$ Lebendgewicht. Zeitschrift für Tierphysiologie, Tierernährung und Futtermittelkunde 41: 177-184.

Hartog, L. A. den, 1984. The effect of energy intake on age at puberty in gilts. Netherlands Journal of Agricultural Science (in preparation).

Homb, T., 1972. Protein utilization in pigs of different weight. Norges Landbrukshøgskole, Sartrykk 384: $61-82$.

Honing, Y. van der, A. W. Jongbloed, B. Smits \& B. J. Wieman, 1982. Effect of substitution of cereals by carbohydrates from different byproducts or animal fat on energy utilization by growing boars. 9th Symposium on Energy Metabolism, Lillehammer, Norway.

Just Nielsen, A., 1970. The energy value of balanced feed rations for growing pigs determined by different methods. Thesis, København, $212 \mathrm{pp}$.

Kidder, D. E. \& M. J. Manners, 1978. Digestion in the pig. Scientechnica, Bristol, 201 pp.

Kielanowski, J., 1972a. Protein requirements of growing animals. In: Handbuch der Tierernährung. Band II. Parey Berlin 528-546.

Kielanowski, J., 1972b. Energy requirements of the growing pig. In: D. Cole (Ed.), Pig production. London, pp. 183-201.

Metz, S. H. M., P. L. Bergström, N. P. Lenis, M. de Wijs \& R. A. Dekker, 1980. The effect of daily energy intake on growth rate and composition of weight gain in pigs. Livestock Production Science 7: 79 87.

NEN-3326, 1966. Onderzoekingen voor veevoeding. Bepaling van het gehalte aan ruwe celstof volgens de verkorte methode. Nederlands Normalisatie Instituut, Delft, 4 pp.

Nie, N. H., C. H. Hull, J. C. Jenhuis, K. Steinbrenner \& D. H. Brent, 1975. Statistical package for the social sciences, 2nd edition. McGraw-Hill.

Nordfeldt, S., 1954. Digestibility experiments with pigs. Kungliga Landbrukshøgskolan Annaler 21: 129. 
Oslage, H. J. \& E. Schulz, 1977. Aminosäurenansatz in verschiedene Organen und Gesamtkörper wachsender Schweine sowie Ableitungen zum Aminosäurenbedarf. 5th International Symposium on Amino Acids, Budapest.

Peers, D. G., A. G. Taylor \& C. T. Whittemore, 1977. The influence of feeding level and level of dietary inclusion on the digestibility of barley meal in the pig. Animal Feed Science and Technology 2:41-47.

Roth, F. X. \& M. Kirchgessner, 1984. Verdaulichkeit der Energie und Rohnährstoffe beim Schwein in Abhängigkeit von Fütterungsniveau und Lebendgewicht. Zeitschrift für Tierphysiologie, Tierernährung und Futtermittelkunde 51: 79-87.

Schiemann, R., K. Nehring, L. Hoffmann, W. Jentsch \& A. Chudy, 1971. Energetische Futterbewertung und Energienormen. VEB Deutscher Landwirtschaftsverlag, Berlin, 344 pp.

Thorbeck, G., 1975. Studies on energy metabolism in growing pigs. II. Beretning Statens Husdyrbrugsfors $\emptyset$, København 424, $193 \mathrm{pp}$.

Wenk, C., 1982. Verdaulichkeit proteinreicher Futtermittel beim wachsenden Schwein. Giessener Tagung, 4 pp.

Wenk, C., H. P. Pfirter \& A. Schürch, 1976. Zur Energie- und Protein versorgung des Mastschweines. Zeitschrift für Tierphysiologie, Tierernährung und Futtermittelkunde 36: 249-266.

Whittemore, C. T. \& R. H. Fawcett, 1974. Model responses of the growing pig to the dietary intake of energy and protein. Animal Production 19:221-231. 